\title{
Bimbingan Belajar Matematika dan Bahasa Inggris Di Kelurahan Bojong Jaya - Tangerang
}

\author{
Year Rezeki Patricia Tantu \\ Universitas Pelita Harapan
}

year.tantu@uph.edu

\begin{abstract}
Abstrak
Kebutuhan yang besar akan pembelajaran yang bermakna untuk meningkatkan kemampuan berhitung dan kemampuan Bahasa Inggris di Kelurahan Bojong Jaya - Tangerang mendorong diadakannya kegiatan Pengabdian kepada Masyarakat $(\mathrm{PkM})$ ini. Kondisi latar belakang ekonomi warga yang bertempat tinggal di kelurahan tersebut sangat berdampak kepada pendidikan yang didapatkan anak-anak usia sekolah dasar. Pendidikan yang dirasakan oleh anak-anak belum maksimal dan memadai. Anak-anak kurang menguasai konsep dasar dalam berhitung dan minim dalam pembelajaran Bahasa Inggris. PkM ini bertujuan untuk menghadirkan pembelajaran bermakna dan menyenangkan sesuai dengan level anak SD dalam meningkatkan kemampuan berhitung dan Bahasa Inggris. Pelaksanaan kegiatan diawali dengan pengamatan dan uji kemampuan dasar matematika dan Bahasa Inggris, penentuan materi dan jadwal tutor, pelaksanaan bimbingan belajar, dan evaluasi. Kegiatan dilakukan pada bulan Januari-Juni 2020, tetapi ada perpanjangan pada bulan Agustus 2020 karena situasi pandemi yang mengakibatkan kegiatan ini terhenti pada bulan April-Juni. Hasil dari kegiatan bimbingan belajar ini adalah meningkatnya motivasi belajar anak, perbendaharaan kata dalam Bahasa Inggris anak bertambah, dan peningkatan kemampuan menguasai konsep dasar berhitung. Hal ini dapat terlihat dari catatan observasi tutor.
\end{abstract}

Kata Kunci : belajar, kemampuan matematika, kemampuan bahasa inggris

\section{PENDAHULUAN}

Belajar adalah proses seumur hidup yang dapat terjadi kapan saja dan di mana saja (Knight, 2009, hal. 16). Dengan belajar, manusia dapat mengembangkan potensi yang dianugerahkan dalam dirinya sehingga mampu menjadi sumber daya manusia yang berkarakter, kompeten, dan unggul. Menurut Undang-Undang Nomor 20 Tahun 2003, Pendidikan adalah usaha sadar dan terencana untuk mewujudkan suasana belajar dan proses pembelajaran agar peserta didik secara aktif mengembangkan potensi dirinya untuk memiliki kekuatan spiritual keagamaan, pengendalian diri, kepribadian, kecerdasan, akhlak mulia, serta keterampilan yang diperlukan dirinya, masyarakat, bangsa dan negara. Sejatinya, pendidikan dimulai dari dalam keluarga dan didukung oleh sekolah dan komunitas masyarakat. Terwujudnya tujuan daripada pendidikan perlu didorong dengan kerja sama dari pihak keluarga, sekolah, serta masyarakat. Dalam media detiknews, 30 Desember 2017 dikatakan bahwa masalah pendidikan menjadi penyumbang lambatnya pembangunan di kawasan Banten. Provinsi yang sangat dekat dengan Ibu Kota Jakarta ini masih begitu lekat dengan 
ketertinggalan, kemiskinan, pengangguran, dan infrastruktur rusak. Ketertinggalan dalam pendidikan tidak hanya ditemukan di daerah $3 \mathrm{~T}$ (tertinggal, terdepan, terluar), tetapi ditemukan juga di area perkotaan. Salah satunya masyarakat Kelurahan Bojong Jaya, Kecamatan Karawaci, Kota Tangerang. Daerah ibukota dari provinsi Banten ini masih memiliki area yang menunjukkan ketertinggalan dalam pendidikan. Menjadi sorotan karena area ini berada dekat dengan perumahan elit, perkantoran, dan beberapa pusat perbelanjaan. Selain itu, area ini tidak dapat dikatakan terisolasi karena akses transportasi sudah memadai. Namun, fenomena mengenai kualitas sumber daya manusa yang tinggal di area kelurahan Bojong Jaya ini masih memprihatinkan oleh karena pengaruh latar belakang ekonomi dan sosial. Hal tersebut berpengaruh kepada cara pandang masyarakat terhadap pendidikan.

Berdasarkan pengamatan yang dilakukan, kondisi kemampuan kognitif dan keterampilan dasar beberapa anak usia sekolah dasar yang berasal dari daerah tersebut belum berkembang maksimal. Semua anak mengecap pendidikan di bangku sekolah dasar, tetapi kemampuan kognitif seperti berhitung dan kemampuan Bahasa Inggris yang dimiliki masih tergolong sangat lemah. Selain kemampuan kognitif, terlihat juga anak-anak masih memiliki percaya diri yang rendah akan potensi yang ada dalam dirinya. Pada akhirnya, anak kurang menonjol dalam bidang seni dan kreativitas.

Asih (2018) dalam jurnalnya mengatakan bahwa tahapan perkembangan kognitif anak usia Sekolah Dasar (SD) 7-11 tahun menurut Piaget berada dalam tahap operasional konkret. Anak-anak SD seharusnya sudah mampu mengelompokkan sesuatu, memahami hubungan sebab akibat, sudah dapat berpikir secara konkret dan logis. Basri (2018) menambahkan bahwa pada tahapan ini, pemikiran logis anak masih sebatas diterapkan pada sesuatu yang konkret, bukan sesuatu yang abstrak. Melihat ciri-ciri daripada perkembangan kognitif anak usia sekolah dasar, maka penting untuk memberikan dukungan pembelajaran bagi anak untuk dapat mengembangkan kemampuan kognitif. Strategi pembelajaran untuk anak usia sekolah dasar perlu dirancang dengan kreatif dan kontekstual untuk menjawab kebutuhan perkembangan kognitif anak. Perlu adanya objek konkret yang dapat menolong anak mengklasifikasi, memahami hubungan sebab akibat, dan berpikir logis. Pembelajaran juga perlu dikaitkan dengan kehidupan sehari-hari anak sehingga mereka menemukan contoh nyata penerapan konsep yang dipelajari.

Mendukung berkembangnya kemampuan kognitif anak, Santrock (2012) menuliskan bahwa perkembangan psikososial anak perlu untuk diperhatikan. Tahapan perkembangan psikososial Erickson untuk anak usia 6-12 tahun berada dalam tahap industry vs inferiority. Pada tahap ini, anak yang rajin dan berprestasi akan menjadi pribadi yang percaya diri, sedangkan ketika anak merasa gagal berprestasi atau tidak memiliki kemampuan yang sama dengan teman sebaya maka anak cenderung akan membantuk sikap rendah diri. Melihat hal tersebut, anak membutuhkan dukungan dari guru, orang tua, dan komunitas sekitar agar bisa mengembangkan potensi diri sehingga anak dapat tampil lebih percaya diri.

Di sisi yang lain, Santrock (2011) mengatakan bahwa di daerah yang penghasilan pekerja rendah, siswa cenderung memikili pencapaian akademik yang rendah juga. Hal tersebut sesuai dengan penelitian yang dilakukan oleh Wirawan (2015), yaitu tingkat pendidikan orang tua yang baik dan pendapatan ekonomi yang cukup dapat meningkatkan prestasi belajar anak. Ditambahkan juga oleh Atika \& Rasyid (2018) bahwa terdapat pengaruh signifikan dan positif antara status sosial ekonomi orang tua dan keterampilan sosial anak. Dijelaskan dalam jurnal tersebut (Sochib, 2010 dalam Atika \& Rasyid, 2018) bahwa orang tua yang berlatar belakang pendidikan rendah akan cenderung lebih memusatkan perhatian pada pemenuhan kebutuhan primer, sedangkan orang tua yang berlatar pendidikan tinggi akan cenderung memusatkan perhatian kepada perkembangan anak. Adapun, orang tua yang berstatus sosial ekonomi menengah lebih mampu memberikan keteladanan dalam mengupayakan kehidupan sosial yang baik.

Berdasarkan kajian beberapa teori perkembangan anak yang dipaparkan di atas, keluarga, sekolah, dan masyarakat berperan penting dalam mendukung perkembangan setiap anak sehingga anak dapat bertumbuh menjadi sumber daya manusia yang kompeten dan unggul kelak.

$$
\text { Pendidikan } 791
$$


Kemajuan bangsa bahkan setiap daerah yang ada tidak terlepas dari adanya sumber daya manusia yang berkualitas. Kondisi fenomena yang terjadi di daerah Tangerang mendorong Universitas Pelita Harapan yang berlokasi cukup dekat dengan area ini mengadakan kegiatan PkM Bimbingan Belajar di luar jam sekolah. Susanto (2018) mengatakan bahwa adanya bimbingan belajar dapat membuka ruang belajar yang nyaman dan efektif, serta dapat meningkatkan motivasi berprestasi siswa. Melalui kegiatan PkM ini diharapkan anak-anak yang diajar mampu menemukan arti penting tentang belajar sehingga mereka mampu mengembangkan kemampuan kognitif, khususnya kemampuan Matematika dan berbahasa Inggris. Selain itu, kegiatan ini bertujuan untuk meningkatkan motivasi belajar anak dan mendorong terbentuknya percaya diri anak melalui kehadiran tutor-tutor yang dapat langsung berinteraksi dekat dengan anak dan membantu kesulitan anak dalam belajar.

Santrock (2011) menuliskan beberapa strategi yang dapat menolong anak yang berada dalam kondisi ekonomi tingkat bawah, yaitu dengan meningkatkan kemampuan berpikir dan bahasa anak, menjadikan motivasi sebagai prioritas bagi mereka, berkolaborasi dengan orang tua dan memberikan dukungan edukasi kepada orang tua, mendorong anak untuk mengembangkan potensi atau kekuatan yang dimiliki. Hadirnya bimbingan belajar di Kelurahan Bojong Jaya ini adalah sebagai salah satu cara untuk menolong anak yang berada dalam kondisi ekonomi tingkat bawah mendapatkan pendidikan yang berkualitas melalui strategi pembelajaran yang efektif dan kreatif sesuai karakteristik perkembangan anak usia sekolah dasar. Oleh karena itu, tujuan kegiatan PkM ini adalah meningkatkan kemampuan kognitif anak usia sekolah dasar, khususnya kemampuan Matematika dan Bahasa Inggris melalui pembelajaran bermakna dan meningkatkan motivasi belajar anak melalui interaksi positif selama bimbingan belajar berlangsung.

\section{METODE}

Kegiatan PkM Bimbingan Belajar dilakukan pada bulan Januari - Agustus 2020. Bimbel diadakan setiap hari Sabtu selama 1 jam pada pukul 15.00-16.30. Kegiatan dilakukan di ruang serbaguna GBI Victoria Park. Jumlah siswa mengikuti kegiatan ini adalah 10 siswa sekolah dasar. Adapun jumlah tutor tetap yang ada berjumlah 3 mahasiswa dari Fakultas Ilmu Pendidikan jurusan Pendidikan Guru Sekolah Dasar. Disediakan juga tutor tambahan yang dapat membantu anak-anak secara mandiri ketika bimbingan belajar ini dilaksanakan.

Metode pelaksanaan kegiatan $\mathrm{PkM}$ ini adalah sebagai berikut: 1) Ketua PkM melakukan analisis kebutuhan melalui beberapa anak-anak dan orang tua yang tinggal di Kelurahan Bojong Jaya; 2) Ketua PkM menentukan permasalahan yang akan ditindaklanjuti melalui pelaksanaan PkM; 3) Ketua PkM menentukan solusi permasalahan, yaitu kegiatan bimbingan belajar untuk meningkatkan kemampuan Matematika dan Bahasa Inggris; 4) Ketua PkM mengadakan brainstorming dengan tutor mahasiswa untuk menentukan rencana pembelajaran; 5) Mencari tutor tambahan dan menyusun jadwal tutor; 6) Ketua PkM dan mahasiswa tutor mengajar peserta bimbel; 7) Ketua PkM dan mahasiswa tutor melakukan evaluasi setelah kegiatan pembelajaran selesai dilaksanakan.

Berikut ini adalah rincian kegiatan PkM yang dilaksanakan setiap Sabtu.

Tabel 1. Kegiatan Bimbingan Belajar

\begin{tabular}{cc}
\hline Kegiatan & Waktu \\
\hline Membariskan tutee \& & $15.00-15.10$ \\
doa pembuka & $15.10-15.30$ \\
Tutoring & $15.30-16.00$ \\
Aktivitas & $16.00-16.10$ \\
Doa penutup \& salam & $16.10-16.30$ \\
Evaluasi tutor &
\end{tabular}

Tabel diatas adalah urutan kegiatan secara umum. Urutan tersebut bersifat fleksibel yang dapat berubah tergantung pada aktivitas yang dipersiapkan tutor, seperti permainan, membaca buku, bernyanyi bersama terlebih dahulu lalu fokus ke materi, dan aktivitas lainnya.

\section{HASIL DAN PEMBAHASAN}

\section{Pelaksanaan Kegiatan}

Kegiatan bimbingan belajar disambut baik oleh orang tua yang tinggal di sekitar kelurahan Bojong Jaya, Tangerang. Kegiatan ini dapat terlaksana dengan baik setiap Sabtu, pukul 15.0016.30. Bimbingan belajar dimulai pada bulan Februari hingga Maret 2020, kemudian terhenti

$$
\text { Pendidikan } 792
$$


pada bulan April-Juli 2020 karena ada pandemi Covid-19 yang melanda. Kegiatan bimbingan belajar dilanjutkan pada bulan Agustus 2020 secara daring melalui zoom. Jumlah siswa yang bergabung adalah 16 anak, didampingi tutor berkisar antara 7-8 orang yang hadir dalam setiap pertemuan. Tutor yang terlibat dapat membimbing 2-3 anak dalam setiap pertemuan.

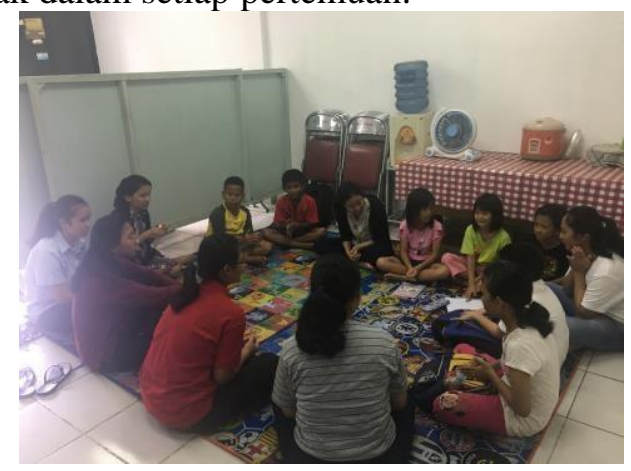

Gambar 1. Kegiatan Pembukaan Pembelajaran

Sebelum memulai pembelajaran, para tutor menyapa keseluruhan siswa dan membuat kegiatan yang dapat menarik perhatian anak seperti main games, bernyanyi, maupun bertanya kabar kepada masing-masing anak. Kegiatan juga dibuka dengan doa menurut keyakinan masing-masing yang dipimpin oleh salah satu anak secara bergantian. Kegiatan ini bertujuan untuk melatih inisiatif dan kepercayaan diri anak untuk memimpin temantemannya dalam hal kecil. Anak-anak diajarkan juga untuk saling mendengar dan menghargai teman ketika sedang berbicara.

Setelah itu, anak-anak masuk dalam kegiatan inti pembelajaran.

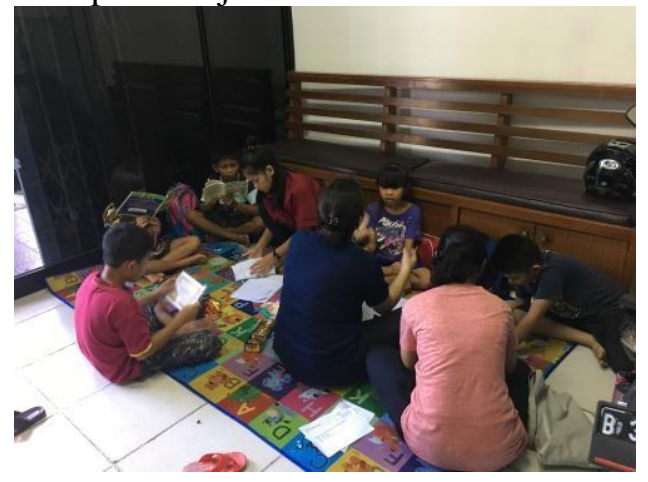

Gambar 2. Kegiatan Inti Pembelajaran
Pada kegiatan inti, setiap tutor mendampingi anak secara individu dalam belajar. Untuk meningkatkan kemampuan Bahasa Inggris, anak diberikan buku bacaan dalam Bahasa Inggris dan diminta untuk menceritakan kembali. Melalui kegiatan tersebut, anak mendapatkan kosakata baru melalui buku yang dibaca. Dalam pembelajaran Matematika, para tutor akan mengajarkan anak tentang konsep materi yang kemudian dilanjutkan dengan latihan soal sesuai dengan kelas masingmasing. Adapun meda pembelajaran yang digunakan untuk mendukung kegiatan bimbel adalah alat tulis, papan tulis, tikar tempat duduk anak, media ajar sesuai dengan konsep yang dibawakan oleh tutor.

Setelah selesai melakukan pembelajaran, kegiatan ditutup dengan doa dan tanya jawab dengan semua anak mengenai hal yang dipelajari dan perasaan anak-anak selama mengikuti kegiatan bimbingan belajar. Para tutor akan mengantarkan anak-anak untuk menyeberang jalan menuju rumah masing-masing. Setelah itu, para tutor akan melakukan evaluasi terkait pembelajaran yang dibawakan.

Selama pelaksanaan kegiatan, kendala terbesar yang ditemui adalah kelengkapan media pembelajaran. Masih ada beberapa alat penunjang seperti meja belajar yang belum sempat terbeli ketika pembelajaran dilaksanakan serta perlu tambahan media ajar yang dapat mendukung pemahaman konsep Matematika. Kendala ini bisa diselesaikan dengan cara para tutor membuat media ajar kreatif dari bahan daur ulang, seperti flash card yang dapat dipakai pada saat pembelajaran.

\section{Hasil Kegiatan}

Berikut ini adalah hasil observasi kegiatan belajar mengajar di Kelurahan Bojong Jaya.

Tabel 2. Hasil Observasi KBM

\begin{tabular}{cl}
\hline Tanggal & \multicolumn{1}{c}{ Hasil Observasi } \\
\hline 8 Feb 2020 & $\begin{array}{l}\text { Anak-anak antusias dalam } \\
\text { belajar, menjawab pertanyaan, } \\
\text { dan mengikuti kegiatan } \\
\text { permainan yang diadakan. } \\
\text { Anak-anak semangat dan mau } \\
\text { belajar. } \\
\text { 15 Feb 2020 } \\
\text { 22 Feb 2020 } \\
\text { pembelajaran dengan baik dan }\end{array}$
\end{tabular}

Pendidikan 793 
aktif. Ada beberapa anak yang masih pasif dan malu. Beberapa siswa masih kurang teliti dalam konsep bilangan ratusan dan ribuan serta perkalian dan pengurangan.

Sebagian besar anak mengikuti pembelajaran dengan antusias bahkan ada yang senang

29 Feb 2020

7 Maret 2020

14 Maret 2020

1 Agustus 2020

8 Agustus 2020

15 Agustus 2020

22 Agustus 2020

29 Agustus 2020 bertanya kepada tutor. Masih ada beberapa siswa yang malu dan tidak percaya diri ketika berbicara Bahasa Inggris.

Anak-anak semangat mengıkut pembelajaran, tetapi masih ada beberapa anak masih kesulitan dalam memahami konsep Matematika.

Anak-anak mengikuti pembelajaran dengan baik dan antusias. Beberapa anak sudah mampu membuat cerita mengenai pengaman sendiri dalam Bahasa Inggris.

Anak-anak antusias meng1kutı pembelajaran sekalipun online via zoom. Mereka mendapat kosakata baru Bahasa Inggris dari storytelling yang dibawakan oleh para tutor.

Anak-anak antusias mengikuti pembelajaran dan mau menjawab pertanyaanpertanyaan yang diberikan oleh tutor.

Anak-anak antusias dan cukup aktif. Ada beberapa yang mengalami kendala teknis (jaringan dan perangkat) sehingga tidak bisa mengikuti pembelajaran secara utuh.

Anak-anak antusias mengikuti pembelajaran dan menjawab pertanyaan-pertanyaan yang diberikan oleh tutor. Beberapa anak ada kendala jaringan sehingga tidak mengikuti pembelajaran secara utuh. Anak-anak antusias mengikuti pembelajaran dan belajar kosakata Bahasa Inggris baru. Beberapa anak dan tutor mengalami kendala jaringan.
Berdasarkan hasil observasi, terlihat bahwa setiap minggu anak-anak yang berasal dari Kelurahan Bojong Jaya mendapat dukungan belajar yang dapat membantu perkembangan kognitif mereka khususnya kemampuan Matematika dan

Bahasa Inggris. Strateg1 tutorial dapat membuat anak bisa lebih bebas untuk bertanya kepada setiap tutor dan lebih menjawab kebutuhan anak terkait konsep yang belum dipahami.

Hasil ini didukung oleh kemampuan para tutor yang menghadirkan pembelajaran yang menarik dan memotivasi anak untuk belajar. Selain itu, para tutor juga terus memperbaiki kualitas pengajaran setiap minggu berdasarkan evaluasi yang dilakukan di akhir pembelajaran. Berikut ini adalah hasil kuisioner penilaian diri para tutor selama mengajar di bimbingan belajar ini: 1) tutor sudah baik dalam menguraikan tujuan pembelajaran dengan jelas; 2) tutor menguasai konsep materi yang diajarkan dengan baik; 3) tutor memberi contoh materi yang mudah dipahami; tutor sudah baik dalam menggunakan media pembelajaran yang kreatif dan sesuai karakteristik anak; 4) tutor menggunakan bahasa yang mudah dipahami anak; 5) tutor bersikap sangat santun dalam mengajar; 6) tutor memotivasi anak untuk berpartisipasi aktif; 7) tutor sudah memberi kesempatan kepada anak untuk menjawab pertanyaan. Hal yang masih perlu ditingkatkan oleh tutor adalah mengecek pemahaman anak setelah belajar.

\section{Pembahasan}

Melalui hasil kegiatan yang dipaparkan di atas, dapat dilihat bahwa kegiatan bimbingan belajar yang diadakan di Keluharan Bojong Jaya dapat menjadi salah satu dukungan untuk membantu terwujudnya kualitas pendidikan yang baik di daerah yang masih dibilang mengalami ketertinggalan dalam pendidikan. Susanto (2018) mengatakan bahwa bimbingan belajar merupakan proses bimbingan yang dapat membantu siswa mengembangkan diri, sikap, dan kebiasaan belajar yang tepat bagi dirinya sendiri untuk menguasai pengetahuan dan keterampilan. Dengan adanya bimbingan belajar ini, anak dapat memiliki pola belajar yang teratur setiap minggu untuk mengasah kemampuan Matematika dan Bahasa Inggris. Selain

kemampuan kognitif yang berkembang, sikap percaya diri perlahan-lahan mulai berkembang

$$
\text { Pendidikan } 794
$$


dalam diri anak melalui aktivitas kecil yang dilakukan, tanggung jawab yang diberikan, dan pujian yang didapat ketika mereka belajar.

Pada beberapa pertemuan, terlihat bahwa anak-anak cukup kesulitan memahami konsep matematika. Sappaile (2012) mengatakan bahwa belajar matematika adalah belajar konsep-konsep dan struktur-struktur serta mencari hubunganhubungan antara konsep dan struktur tersebut. Konsep matematika yang abstrak tidak dapat dikomunikasikan dengan definisi, tetapi dengan memberikan contoh-contoh konkret yang sesuai dengan materi pelajaran. Hal ini tentunya sesuai dengan perkembangan kognitif anak usia sekolah dasar yang masih berpikir secara konkret. Dalam proses bimbingan belajar, para tutor terus melakukan evaluasi dan mengembangkan strategi mengajar yang menggunakan objek konkret serta contoh nyata yang dekat dengan kehidupan anak sehingga anak dapat lebih mudah memahami konsep matematika.

Pada awal pembelajaran, sebagian anak belum menguasai Bahasa Inggris. Sebagian lagi menguasai Bahasa Inggris, tetapi masih kurang percaya diri ketika diminta untuk berbicara. Maili (2018) berkata bahwa pada zaman globalisasi dimana semua sistem sudah menggunakan bahasa Inggris otomatis, perlu pengetahuan dasar yang diajarkan kepada anak sejak dini. Hal ini juga yang menjadi fokus dalam bimbingan belajar ini, yaitu memperkenalkan anak usia sekolah dasar tentang Bahasa Inggris dan membuat anak percaya diri untuk menggunakannya. Wijaya (2015) mengatakan bahwa salah satu pendekatan atau strategi yang dapat membawa anak memperoleh pemahaman mendalam tentang bahasa Inggris adalah menekankan keterlibatan peserta didik untuk mengkaitkan materi pembelajaran yang dipelajari dan menghubungkannya dengan situasi kehidupan nyata sehingga mendorong peserta didik untuk mampu menerapkannya dalam kehidupan atau lingkungan mereka sehari-hari. Ketika mengajar, para tutor selalu membawa anak kepada tema-tema yang terkait dengan kehidupan sehari-hari anak. Misalnya: saat tema yang diajarkan tentang keluarga (family), anak-anak diarahkan untuk mengenal sapaan untuk ayah, ibu, kakak, adik, kakek, nenek, paman, bibi, saudara sepupu, kemudian anak-anak diminta untuk mengenalkan keluarga mereka dengan menggunakan bahasa Inggris. Strategi tersebut membuat anak lebih mudah memahami karena dapat langsung diaplikasikan dan dekat dengan kehidupan anak.

Berdasarkan evaluasi diri tutor, terlihat bahwa tercapainya tujuan dari bimbingan belajar ini tidak lepas dari peran para tutor yang mengajar. Andini \& Supardi (2018) mengatakan bahwa pembelajaran dapat berjalan dengan efektif ketika guru memiliki kompetensi pedagogik. Para tutor merupakan mahasiswa calon guru yang sedang dipersiapkan untuk mengajar anak SD sehingga mereka sudah dibekali dengan kemampuan pedagogi dan konten untuk dapat mengajar anak SD. Ketika ada anak yang belum memahami konsep Matematika, tutor menjelaskan konsep dengan menggunakan contoh konkret serta media ajar yang dapat membantu siswa memahami konsep. Tutor juga terus mengevaluasi pembelajaran dengan menghadirkan metode pembelajaran yang kreatif dan variatif sehingga menolong anak untuk menikmati pembelajaran. Melalui kegiatan ini, para tutor juga mendapat manfaat dalam melatih kemampuan mengajar anak SD sekalipun masih bersifat tutorial. Hal yang menjadi perhatian bagi para tutor adalah pengecekan pemahaman setelah kegiatan bimbingan belajar selesai dilakukan. Mengecek pemahaman sangat penting untuk dilakukan karena melalui kegiatan tersebut kita bisa melihat tercapainya tujuan pembelajaran yang ditentukan. Para tutor perlu memanajemen waktu dengan baik sehingga kegiatan pengecekan pemahaman dapat diadakan setelah kegiatan berlangsung.

\section{KESIMPULAN}

Kegiatan bimbingan belajar yang dilakukan di Kelurahan Bojong Jaya sangat bermanfaat bagi anak-anak usia sekolah dasar yang berdomisili di daerah tersebut dalam mengembangkan kemampuan kognitif mereka khususnya kemampuan Matematika dan Bahasa Inggris. Selain itu, kegiatan ini juga berdampak mengembangkan motivasi belajar dan sikap percaya diri anak.

Melihat hasil pelaksanaan, kegiatan bimbingan belajar ini disarankan untuk tetap dilaksanakan bagi anak-anak yang ada di sekitar kelurahan Bojong Jaya. Perlu juga untuk 
menjangkau lebih banyak anak yang berdomisili di sekitar kelurahan tersebut, tetapi belum mengetahui keberadaan dari bimbingan belajar yang dilakukan melalui kerja sama dengan pihak kelurahan. Selain itu, kegiatan ini baiknya didampingi dengan edukasi bagi para orang tua mengenai dukungan yang perlu dilakukan orang tua agar dapat memaksimalkan perkembangan anak.

\section{UCAPAN TERIMAKASIH}

Ucapan terimakasih disampaikan kepada LPPM Universitas Pelita Harapan yang telah mendukung dalam dana sehingga kegiatan ini bisa terlaksana.

\section{REFERENSI}

Andini, D. M. \& Supardi, E. (2018). Kompetensi Pedagogik Guru terhadap Efektivitas Pembelajaran dengan Variabel Kontrol Latar Belakang Pendidikan Guru. Jurnal Pendidikan Manajemen Perkantoran, 3(1): 149-155.

Asih, T. (2018). Perkembangan Tingkat Kognitif Peserta Didik di Kota Metro. Didaktika Biologi: Jurnal Penelitian Pendidikan Biologi, 2(1): 9-17. https://doi.org/10.32502/dikbio.v2i1

Atika, A. N. \& Rasyid, H. (2018). Dampak Status Sosial Ekonomi Orang Tua terhadap Keterampilan Sosial Anak. Pedagogia: Jurnal Pendidikan, 7(2): 111-120.

Basri, H. (2018). Kemampuan Kognitif dalam Meningkatkan Efektivitas Pembelajaran Ilmu Sosial bagi Siswa Sekolah Dasar. Jurnal Penelitian Pendidikan, 18(1): 1-9.

Knight, G. R. (2009). Filsafat \& pendidikan: Sebuah pendahuluan dari perspektif Kristen. Jakarta: Universitas Pelita Harapan.

Maili, S. N. (2018). Bahasa Inggrs pada Sekolah Dasar: Mengapa Perlu dan Mengapa Dipersoalkan. Jurnal Pendidikan Unsika, 6(1): 2328.

Santrock, J. W. (2011). Educational Psychology. New York: McGraw-Hill

Santrock, J. W. (2012). Adolescence: Perkembangan Remaja. Jakarta: Erlangga.

Sappaile, B. I. (2012). Menumbuhkan Motivasi Belajar Matematika Peserta Didik Sekolah Belajar. Jurnal Pendidikan Matematika, 3(1): 6374.

Susanto, A. (2010). Bimbingan dan Konseling di Sekolah: Konsep, Teori, dan Aplikasinya. Jakarta: Prenadamedia Group.

Wijaya, I. K. (2015). Pembelajaran Bahasa Inggris di Sekolah Dasar. Jurnal Pendidikan Bahasa dan Sastra, 14(2): 120 128. https://doi.org/10.21009/BAHTERA.142.02

Wirawan, Y. R. (2015). Pengaruh Status Sosial Ekonomi Orang Tua terhadap Prestasi Belajar Ekonomi dan Perilaku Konsumsi Siswa. Jurnal Ekonomi Pendidikan dan Kewirausahaan, 3(2):

147-167.

http://dx.doi.org/10.26740/jepk.v3n2.p147-167 